\title{
IIIISGUC.ORG
}

"iș, GÜC̣" ENDÜSTRi iLIȘKiLERi VE INSAN KAYNAKLARI DERGiSi

"IS, GUC" INDUSTRIAL RELATIONS AND HUMAN RESOURCES JOURNAL

\section{Nursing Staff Work Experiences, Work Outcomes and Psychological Well-Being in Difficult Times: Implications For Improving Nursing Staff Quality Of Work Life and Hospital}

\author{
Ronald J. Burke \\ York University \\ Eddy W. S. Ng \\ Dalhousie University \\ Jacob Wolpin \\ Independent Consultant
}

Nisan/April 2011, Cilt/Vol: 13, Say1/Num: 1, Page: 7-22

ISSN: 1303-2860, DOI: 10.4026/1303-2860.2010.0170.x

Makalenin on-line kopyasına erişmek için:

http://www.isguc.org/?p=article\&id=461\&vol=13\&num=2\&year=2011

To reach the on-line copy of article:

http://www.isguc.org/?p=article\&id=461\&vol=13\&num=2\&year=2011

Makale İçin İletişim/Correspondence to: 
(C) 2000- 2011

"İşGüç" Endüstri İlişkileri ve İnsan Kaynakları Dergisi

"İşGüç" Industrial Relations and Human Resources Journal

Nisan/April 2011, Cilt/Vol: 13, Say1/Num: 1

ISSN: 1303-2860, DOI: 10.4026/1303-2860.2010.170.x

Editör/Editor-in-Chief

Aşkın Keser (Kocaeli University)

Editör Yardımcıları/Co-Editors

K.Ahmet Sevimli (Uludağ University)

Gözde Yılmaz (Kocaeli University)

Uygulama/Design

Yusuf Budak (Kocaeli Universtiy)

\author{
Yayin Kurulu / Publishing Committee \\ Dr.Zerrin Firat (Uludă̆ University) \\ Doç.Dr.Așkm Keser (Kocaeli University) \\ Prof.Dr.Ahmet Selamoğlu (Kocaeli University) \\ Yrd.Doç.Dr.Ahmet Sevimli (Uludağ University) \\ Yrd.Doç.Dr.Abdulkadir Şenkal (Kocaeli University) \\ Yrd.Doç.Dr.Gözde Yilmaz (Kocaeli University) \\ Dr.Memet Zencirkıran (Uludă̆ University)
}

Uluslararası Danışma Kurulu / International Advisory Board

Prof.Dr.Ronald Burke (York University-Kanada)

Assoc.Prof.Dr.Glenn Dawes (James Cook University-Avustralya)

Prof.Dr.Jan Dul (Erasmus University-Hollanda)

Prof.Dr.Alev Efendioğlu (University of San Francisco-ABD)

Prof.Dr.Adrian Furnham (University College London-İngiltere)

Prof.Dr.Alan Geare (University of Otago- Yeni Zellanda)

Prof.Dr. Ricky Griffin (TAMU-Texas AEM University-ABD)

Assoc. Prof. Dr. Diana Lipinskiene (Kaunos University-Litvanya)

Prof.Dr.George Manning (Northern Kentucky University-ABD)

Prof. Dr. William (L.) Murray (University of San Francisco-ABD)

Prof.Dr.Mustafa Özbilgin (University of East Anglia-UK)

Assoc. Prof. Owen Stanley (James Cook University-Avustralya)

Prof.Dr.Işık Urla Zeytinoğlu (McMaster University-Kanada)

Danışma Kurulu / National Advisory Board

Prof.Dr.Yusuf Alper (Uludağ University)

Prof.Dr.Veysel Bozkurt (Uludağ University)

Prof.Dr.Toker Dereli (Işık University)

Prof.Dr.Nihat Erdoğmuş (Kocaeli University)

Prof.Dr.Ahmet Makal (Ankara University)

Prof.Dr.Ahmet Selamoğlu (Kocaeli University)

Prof.Dr.Nadir Suğur (Anadolu University)

Prof.Dr.Nursel Telman (Maltepe University)

Prof.Dr.Cavide Uyargil (İstanbul University)

Prof.Dr.Engin Yildirum (Sakarya University)

Doç.Dr.Arzu Wasti (Sabancı University)

Dergide yayınlanan yazılardaki görüşler ve bu konudaki sorumluluk yazarlarına aittir.

Yayınlanan eserlerde yer alan tüm içerik kaynak gösterilmeden kullanılamaz.

All the opinions written in articles are under responsibilities of the outhors.

None of the contents published can't be used without being cited. 


\title{
Nursing Staff Work Experiences, Work Outcomes and Psychological Well-Being in Difficult Times: Implications For Improving Nursing Staff Quality Of Work Life and Hospital ${ }^{*}$
}

\author{
Ronald J. Burke \\ York University
}

\author{
Eddy W. S. Ng \\ Dalhousie University
}

\author{
Jacob Wolpin \\ Independent Consultant
}

\begin{abstract}
:
Nurses are the largest group of employees in the health care sector and play an important role in the delivery of high quality heath care. Unfortunately recent research has indicated that nursing staff in various countries have reported relatively modest levels of work satisfaction. Several countries are facing nursing shortages and the nursing profession has become a less attractive job and career prospect for young women and men. This investigation examines the relationship of six work experiences proposed by Leiter and Maslach (2005) as antidotes to burnout with various work and well-being outcomes in a sample of US nurses $(N=289)$ whose hospitals were undergoing restructuring and budget cuts. The data indicated that high workloads and low levels of reward, control and value congruence were associated with greater nursing staff distress. Suggestions for addressing these job and work experiences are offered along with approaches to implementing restructuring and downsizing processes more likely to contribute to individual and hospital health.
\end{abstract}

Keywords: Nursing staff, Work experiences, Work outcomes, Quality of Work Life, Psychological Well-being

\footnotetext{
* Preparation of this manuscript was supported in part by York University, the School of Business, Dalhousie University and the California State Polytechnic University-Pomona. We thank our respondents for their participation in the research.
} 
Nurses are the largest group of employees in the health care system and play an important front-line role in the delivery of high quality patient care (Aiken, Smith \& Lake, 1994). Nurses typically bring high levels of skill, professionalism, commitment and dedication to their work Unfortunately, research studies conducted in a number of countries over the past 20 years indicate that nurses are increasingly reporting job dissatisfaction and young women and men are less interested in training to become nursing staff. (Aiken, Clarke, Sloane \& Sochalski, 2001; McKee, Aiken, Rafferty \& Sochalski, 1998; Muller-Mundt, 1997; Sochalski, Aiken \& Fagin, 1997). Many countries are now facing shortages of nurses. The nursing profession seems to be in difficulty (Baumann \& Blythe, 2003; Baumgart, 1997; Buchan, Hancock \& Rafferty, 1997; Reinhardt, 1996)

Why are nursing staff now less satisfied? Signs of nursing dissatisfaction appeared in the early to mid-1990s as hospitals undertook restructuring and downsizing initiatives in response to lower levels of financial support from country or regional governments (Aiken \& Fagin, 1997; Aiken, Sochaski \& Anderson, 1996; Armstrong-Stassen, Cameron \& Horsburgh, 1996; Blythe, Baumann \& Giovannetti, 2001; Brannon, 1996; Brown, Arnetz \& Petersson, 2003; Burke, 2004; Kovner \& Gergen, 1998; Laschinger, Sabiston, Finegan \& Shamian, 2001 ; Mesch, McGrew, Pescosolido \& Haugh, 1999; Robertson \& Dowd, 1996; Shanahan, Brownell \& Roos, 2001; Shortell, O'Brien \& Carman, 1995; Woodward, Shannon, Cunningham, McIntosh, Lendrum, Rosenblum \& Brown, 1999). These researchers reported that these restructuring and downsizing efforts were associated with increased levels of job dissatisfaction, higher levels of exhaustion and cynicism (burnout), high levels of psychological distress, a negative impact on hospital functioning, lower levels of hospital upkeep, and greater intentions to leave the profession

Now, almost two decades later, the health care sector is again the target of restructuring, downsizing and cost cutting as governments again attempt to deal with budget shortfalls.

The present study examines the relationship of particular work experiences with a variety of individual and unit/hospital outcomes in a sample of nursing staff working in health care settings (hospitals) undergoing significant restructuring and downsizing. The sample worked in hospitals near Los Angeles California, a state undergoing dramatic budget cuts in response to the recent world-wide economic recession. State workers in California have lost their jobs, been required to take unpaid days off work, and hiring freezes have been imposed on all government departments.

Are there work experiences being reported by nursing staff that are associated with positive personal and hospital outcomes? If these could be identified, it would provide information to nursing administrators on how they might build these into the nursing work environment in an effort to rebuild satisfaction, commitment and morale.

Leiter and Maslach (2005) identified six work experiences as antecedents of burnout in the workplace as well as offering suggestions on how shortfalls or mismatches in these sic areas might be addressed. These work experiences were:

Workload - too much work, work too complex, deadlines too tight, no time to slow down

Control - too little control, personal control is undercut, little input to what going on in your job

Reward - no recognition, not being paid enough, job not satisfying, too little joy at work

Community - conflict with co-workers, difficult patients, abusive supervisors

Fairness - favoritism is common, treated unfairly, arbitrary decisions and rules

Values - conflict between your values 
and the hospitals, no longer believe in hospital values.

Leiter and Maslach also developed reliable measures of these six work experiences. Studies have shown that in general, individuals scoring higher on these work experiences indicating a better fit or match between individual wants and expectations and their reported work experiences, indicate higher levels of work engagement and lower levels of burnout (Leiter \& Maslach, 2005)

The following general hypotheses were considered.

1. Nursing staff scoring lower and workload and higher on control, reward, community, fairness and values would be more satisfied, more work engaged, less "burned out", less absent, less likely to intend to quit, fewer psychosomatic symptoms and less medication use..

2. Nursing staff scoring lower on workload and higher on control, reward, community, fairness and values would indicate a less negative impact of hospital restructuring and downsizing on hospital functioning, a less negative impact of restructuring and downsizing on hospital impact, and a less negative impact of restructuring and downsizing on their job future security.

The central issue was whether these work experiences would be associated with desired individual and hospital outcomes among nursing staff working in trying circumstances.

\section{Method}

\section{Procedure.}

Data were collected from nursing staff using two approaches. First, data were collected for a hospital located in the western United States. The Vice-President of Nursing and Patient Care distributed approximately 300 survey questionnaires to the hospital's staff nurses on behalf of the rese- arch team. A \$5 Starbucks gift cared was offered to the nurse participants. A total of 67 surveys were returned resulting in a response rate of about $22 \%$. Second, additional data were collected online using Surveymonkey from graduate nursing students. These students were enrolled in a graduate nursing program (a Masters degree) at a large public university and all had current work experience (i.e., were working either full-time or part-time). A total of 222 nursing staff enrolled in the Masters program responded to the on-line survey and each respondent also received a $\$ 5$ Starbucks gift card for their participation. The combined sample $(n=289)$ is best described as a convenience sample.

\section{Respondents}

Table 1 presents personal demographic and work situation characteristics of the nursing sample $(\mathrm{n}=289)$. The sample was primarily female (92\%), with spouses/partners (73\%), with children (77\%), typically two children (35\%), worked full-time $(79 \%)$, had supervisory duties $(59 \%)$, had 5 years or more of unit tenure $(47 \%), 10$ years of more of hospital and nursing tenure ( $44 \%$ and $59 \%$, respectively), had not changed units in the past year $(90 \%)$, worked in a variety of nursing units, worked in hospitals having 250 or more beds $(74 \%)$, worked 35-44 hours per week (66\%), had a Bachelor's of Nursing degree (50\%), were between 36 and 55 years of age $(60 \%)$, and lived in communities of varying sizes.

\section{Measures}

\section{Work experiences}

The six work experiences were measured by scales developed by Leiter and Maslach (2005). Respondents indicated their agreement with each item on a five point Likert scale ( $1=$ strongly disagree, $3=$ neutral, $5=$ strongly agree). Workload had 6 items (alpha=.70). A sample item was "I work intensely for prolonged periods of time." Control had 3 items (alpha=.77). A sample item was "I have control over how I do my 
Table 1

Demographic Characteristics of Sample

Supervisory Duties
Yes
No

Hospital Tenure

3 years or less

3-5 years

$5-10$ years

10 years or more

Work Status

Full-time
Part-time
Changed Units
Yes
No

Hospital Size 400 or more beds $251-400$ beds $151-250$ beds 150 beds or less

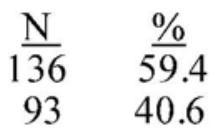

$\frac{\text { Unit Tenure }}{\text { Less than } 4}$

4-5 years

5 years or more

$\begin{array}{rr}\frac{\mathrm{N}}{106} & \frac{\%}{46.3} \\ 16 & 7.0 \\ 107 & 46.7\end{array}$

$\begin{array}{rr}59 & 25.8 \\ 31 & 13.5 \\ 38 & 13.6 \\ 101 & 44.1\end{array}$

\section{Nursing Tenure}

$\begin{array}{lll}180 & 8.9 \quad \text { Nursing Unit }\end{array}$

$48 \quad 21.1$

$24 \quad 10.5$

$205 \quad 89.5$

Hours Worked

34 hours of less

35-39 hours

40-44 hours

45 hours or more

83

84

29

29

44

73

63

47

19.4

32.2

27.8

Education

RN

BA Nursing

MA Nursing

PhD Nursing

65

116

46

2

Marital Status

Married/cohabiting 167

72.9

Single/not cohabiting 62

28.4

50.7

20.1

Gender

Male

$\begin{array}{cc}\frac{\mathrm{N}}{17} & \frac{\%}{7.5} \\ 211 & 92.5\end{array}$

3 years or less

3-5 years

5-10 years

10 years or more

.9

Education

Emergency

Intensive Care

Medical/Surgical

Neonatal

Obstetrics

Telemetry

Size of community

Over 1 million

500,000-1 million

250,000-500,000

$100,000-250,000$

Under 100,000

Age

35 years or younger

$36-45$ years old

37

19

16.3

$\begin{array}{ll}37 & 16.3\end{array}$

$134 \quad 59.0$

46-55 years old

56 years or older

Parental Status

\section{Children}

No children

$47 \quad 21.5$

$\begin{array}{ll}41 & 18.7\end{array}$

$55 \quad 25.1$

$48 \quad 21.0$

$30 \quad 13.8$

$52 \quad 23.3$

$54 \quad 24.2$

$\begin{array}{ll}79 & 35.4\end{array}$

$38 \quad 17.0$

27.1

$\begin{array}{lcc}\text { Number of Children } & \frac{\mathrm{N}}{\mathrm{\%}} \\ 0 & 53 & 23.1 \\ 1 & 31 & 13.5 \\ 2 & 81 & 35.4 \\ 3 & 39 & 17.0 . \\ 4 \text { or more } & 25 & 11.0\end{array}$

Administration 
work." Reward had 4 items (alpha=.85). One item was "My work is appreciated." Community contained 5 items (alpha $=.82$ ). One item was "Members of my work group communicate openly." Fairness had 6 items (alpha $=.81$ ). One item was "Favoritism determines how decisions are made at work" (reversed). Values contained 5 items (alpha=..86). An item was "My values and the hospital's values are alike." These six measures had levels of reliability that were acceptable and consistent with those previously reported (Leiter \& Maslach, 2005)

\section{Work outcomes}

Three work outcomes were included. Job satisfaction was measured by a 5-item scale (alpha =.87) developed by Quinn and Shepard (1974). One item was "All in all, how satisfied would you say y0ou are with your job? ( $1=$ very satisfied, $4=$ not at all satisfied).

Absenteeism was measured by two items (alpha=.76). "How many days of scheduled work have you missed in the past month?" (1=none, $4=$ three or more days).

Intent to quit was measured by a single item. "Taking everything into account how likely is it that you will make a genuine effort to find a new job with another employer within the next 12 months?" (1=very likely, $3=$ not at all likely).

\section{Work engagement}

Three dimensions of work engagement were included using measures developed by Schafeli and Bakker (2003). Vigor was assessed by 6 items (alpha=.81). One item was "At my work, I feel that I am bursting with energy." Dedication was assessed by 5 items (alpha=.89) A sample item was "My job inspires me". Absorption was measured by 6 items (alpha=.84). An item was "I get carried away when I'm working." The reliabilities of these measures were typical of those reported by others (see Bakker \& Leiter, 2010).

\section{Burnout}

Three dimensions of burnout were considered, each measured by the Maslach Burnout Inventory (MBI) developed by Maslach, Jackson and Leiter (1996) Respondents indicated how often they experienced particular feelings on a 7-point scale ( $0=$ never, $6=$ every day)..Emotional exhaustion was measured by a 5-item scale (alpha=.91). An item was "I feel emotionally drained from my work.: Cynicism was assessed by a 5 -item scale (alpha=.88). One item was "I have become more cynical about whether my work contributes anything." Professional efficacy was measured by a 6item scale (alpha=. 82) A sample item was "At my work, I feel confident that I am effective at getting things done.". These three measures had acceptable levels of reliability and the values were consistent with others previously reported (Maslach, Jackson \& Leiter, 1996).

\section{Psychological well-being}

Three aspects of psychological wellbeing were included. Psychosomatic symptoms were measured using a 30-item scale (alpha $=.92$ ) developed by Derogatis, Lipman, Rickels, Uhlenhuth and Covi (1974). Respondents indicated on a 4-point scale ( $1=$ never, $4=$ extremely often) how often they experienced particular symptoms during the past three months (e.g., headaches, poor appetite, pain in the lower part of you back, faintness or dizziness). Medication use was measured by 5 items (alpha $=.62$ ) developed by Quinn and Shepard (1974) Respondents indicated how often they took each medication ( $1=$ never, $5=\mathrm{a}$ lot). Items included pain medication, sleeping pills, and tranquilizers such as Valium. Life satisfaction was measured by a 5 item scale (alpha=..89)also developed by Quinn and Shepard (1974). Respondents indicated their agreement with each item (e.g., In most ways my life is close to idea) on a sevenpoint Lkert agreement scale (1=strongly agree, $4=$ neither agree or disagree, $7=$ strongly disagree). 


\section{Hospital-level measures}

Three hospital-level perceptual measures were included. Impact of restructuring on hospital functioning was measured by 7 items (alpha=.94). Respondents indicated their agreement with each item indicating their views on the effects of restructuring and budget cuts using a 5 pint Likert scale ( $1=$ =strongly disagree, $3=$ neutral, $5=$ strongly agree). Items included "Lowered the quality of health care provided to our patients" and "Required nursing staff to perform more maintenance/housekeeping duties: Impact on hospital facilities was measured by an 8 item scale (alpha=.92). Respondents indicated the extent of changes in their hospital during the past year (1=gotten worse, $3=$ about the same; $5=$ improved).. Items included "level of cleanliness", and "repairs to hospital buildings"

Impact on future job security was measured by 7 items (alpha=.84). Respondents indicated their views on the likelihood of particular work events or actions happening to them on a 4 point scale (1=highly unlikely, $4=$ almost certain) Items included layoff, demotion, and change in employment status to part-time.

\section{Results}

\section{Evidence for "trying times"}

Previous research, involving both the health care sector as well as the private business sector, has indicated that organizational restructuring and downsizing efforts were almost always associated with increased employee dissatisfaction, increased levels of job stress, higher levels of psychological distress and greater intentions to leave the organization (Burke \& Nelson, 1998; Gowing, Kraft \& Quick, 1998; Kets de Vries \& Balacs, 1997; Noer, 2003; O'Neill \& Lenn, 1995; Wright \& Barling, 1998). A measure of the extent of restructuring initiatives in their hospitals was included to provide an assessment of the demands that current restructuring efforts were making on nursing staff. This measure had been used in an earlier study of health care restructuring and downsizing in Ontario Canada during the mid 1990s. Respondents indicated for each of 16 potential restructuring initiatives (alpha $=.82$ ) which ones had been undertaken in their hospitals in the preceding year (1=yes, $2=$ no) Items included: budget cuts, closing of hospital beds, limits on overtime hours and a hiring freeze. Respondents in the present sample indicated a mean of 10.1 initiatives during the past year, similar to the mean of 10.6 in the Ontario Canada nursing sample, indicated fairly widespread efforts to restructure and downsize. Nursing staff indicating a greater number of restructuring initiatives in their hospitals reported lower levels of job satisfaction, greater psychological distress, greater quit intentions and more negative perceptions of hospital functioning in the Ontario Canada study (Burke, 2004, 2003)

\section{Descriptive statistics}

The six work experiences were all significantly inter-correlated (workload being negatively correlated with the other five work experiences, the others being significantly and positively correlated. Correlations ranged from -.33 (Workload and Value fit, to .66 (Fairness and Value fit) The mean inter-correlation was .45 $(\mathrm{p}<.001, \mathrm{n}=268)$.

\section{Analysis plan}

Hierarchical regression analyses were undertaken with predictor variables entered in particular blocks. The first block of predictors were personal demographics $(n=5)$ which included, age, level of education, and marital status. The second block of predictors included work situation characteristics $(n=5)$ such as supervisory responsibilities, hospital size, and nursing unit tenure. The third block of predictors included the six work experiences, the main variables of interest. When a block of predictors accounted for a significant amount or increment in explained variance on a given outcome measures $(p<.05)$, individual items or measures within such blocks having significant and independent relationships with this outcome 
were then identified $(\mathrm{P}<.05)$. This approach to analysis shows the relationship of the work experiences with a given outcome controlling for the effects of both individual personal demographics and work situation characteristics.

\section{Work experiences and work outcomes}

Table 2 presents the results of hierarchical regression analyses in which various work outcomes were separately regressed on the three blocks of predictors. The following comments are offered in summary.

\section{Work engagement}

Work experiences showed an increment in explained variance on all three measures of work engagement. Nursing staff indicating higher levels of Reward and Value fit reported higher levels of Dedication ( $\mathrm{Bs}=.20$ and .20, respectively); nursing staff indicating higher levels of Workload and Control reported higher levels of Absorption ( $\mathrm{Bs}=.24$ and .22 , respectively).

\section{Burnout}

Work experiences produced a significant increment in explained variance on all three indicators of burnout. Nursing staff reporting higher Workloads and lower levels of Control reported higher levels of Exhaustion (Bs=.41 and -.18, respectively). Nursing staff reporting higher Workloads and fewer Rewards indicted higher levels of Cynicism (Bs=.37 and -..20, respectively); and nursing staff reporting fewer Rewards indicated less Professional Efficacy $(\mathrm{B}=-.30)$

\section{Work experiences, work attitudes and beha- viors}

Work experiences accounted for a significant increment in explained variance on two the three measures of work attitudes and behaviors. (not Absenteeism). Nursing staff reporting a stronger Value fit and lower workloads were more job satisfied (Bs=.25 and -.17, respectively); and nursing staff indicating a greater Value fit, more positive Community connections, and lower Work- load were well likely to intend to quit (Bs=.22, .19 and -.16 , respectively)

\section{Work experiences and Psychological health}

Table 3 shows the results of hierarchical regression analyses in which three measures of psychological health were separately regressed on the three blocks of predictors. Work experiences accounted for a significant increment in explained variance on two of the three measures of psychological health (not Medication use). Nursing staff reporting higher levels of Workload and lower levels of Control reported more Psychosomatic symptoms (Bs=.41 and -.18, respectively) and nursing staff reporting higher levels of Reward indicated higher levels of Life satisfaction $(B=, 22)$.

Here

Enter Table 3 About

\section{- - \\ Work experiences and Hospital functio- ning}

Table 4 shows the results of hierarchical regression analyses in which three measures of hospital-based perceptions were separately regressed on the three blocks of predictors. The following comments are offered in summary. First, work experiences accounted for a significant increment in explained variance on the three nursing staff perceptions of hospital functioning. But only on Impact of Restructuring did particular work experiences have independent and significant relationships with this outcome. Nursing staff indicating higher levels of workload and lower levels of both Fairness and Value fit reported a more negative impact of hospital restructuring $(\mathrm{Bs}=.23,-.26$ and -.20 , respectively).

Two observations are worth noting. First, work experiences accounted for a greater increment in explained variance on every outcome measures than did personal 
Table 2

Work Experiences and Work Outcomes

Work Outcomes

Work Engagement

Vigor $(\mathrm{N}=186)$

Personal demographics

Work situation characteristics

Work experiences

$\begin{array}{lccc}\frac{\mathrm{R}}{.15} & \frac{\mathrm{R} 2}{.02} & \frac{\text { Change R2 }}{.02} & \mathrm{P} \\ .21 & .04 & .02 & \mathrm{NS} \\ .41 & .17 & .13 & .001\end{array}$

Dedication $(\mathrm{N}=190)$

Personal demographics

Work situation characteristics

.11

.19

Work experiences

.01

04

.01

.03

NS

Reward (.20)

Value fit $(.20)$

Absorption $(\mathrm{N}=183)$

Personal demographics

Work situation characteristics

Work experiences

Workload (.24)

Control (.22)

Burnout

Exhaustion ( $\mathrm{N}=190)$

Personal demographics

Age (-.15)

Work situation characteristics

Work experiences

Workload (.41)

Control (-.18)

Cynicism ( $\mathrm{N}=188)$

Personal demographics

Work situation characteristics

Work experiences

Workload $(.22)$

Reward (-.20)

Efficacy $(\mathrm{N}=185)$

Personal demographics

Work situation characteristics

.16

.01

Work status (.17)

Work experiences

Reward (.30)

\begin{tabular}{l} 
Job Satisfaction $(\mathrm{N}=181)$ \\
\hline Personal demographics \\
Work situation characteristics \\
Work experiences \\
Value fit $(.25)$ \\
Workload $(-.17)$
\end{tabular}

\section{.27}

.07

.07

.05

.11

.04

.33

NS

.44

.001

Absenteeism $(\mathrm{N}=188)$

Personal demographics

Work situation characteristics

Work experiences

\section{.04}

.08

.44

\section{.04}

.04

NS

$.36 \quad .001$

Intent to Quit ( $\mathrm{N}=189)$

Personal demographics

Work situation characteristics

Work experiences

NS

$\underline{\mathrm{R} 2}$

Value fit (-.22)

Community (-.19)

Workload (.16)

.17

20 


\section{Table 3}

Work Experiences and Psychological Well-Being

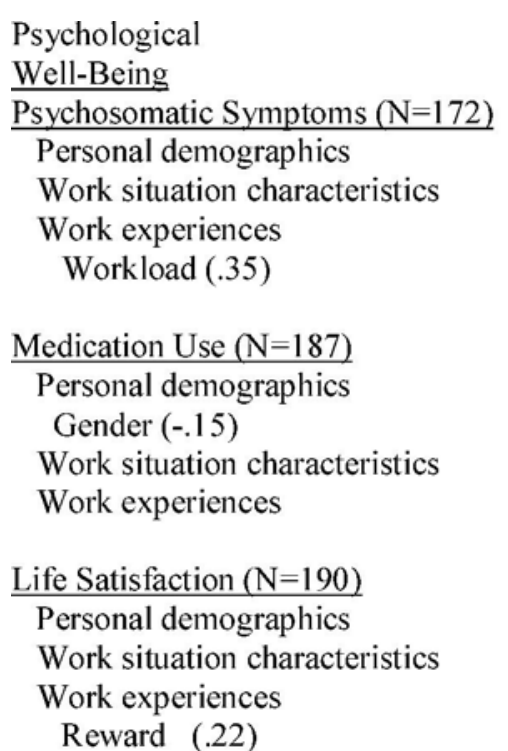

demographic factors and work situation characteristics. Second, some work experiences, notably Workload, Control, Reward, and Value fit had significant and independent relationships with several of the outcome measures.

\section{Discussion}

The results obtained here (see Tables 2,3 and 4) provided considerable support for the hypotheses underlying the research and were consistent with Leiter and Maslach's writing and research (2005) on the role of particular work experiences in reducing burnout and increasing individual and organizational health. Let us now consider practical implicates of this work.

Leiter and Maslach (2005) describe their program for changing an individual's relationship with their work. It begins with individuals self-assessments of their work experiences to identify areas of "mismatch"high Workload and low levels of the other five work experiences. Then once these areas are determined, individuals develop a plan of action. This involves setting goals or directions for change, taking action, and

\begin{tabular}{|c|c|c|c|}
\hline$\underline{\mathrm{R}}$ & $\underline{\mathrm{R} 2}$ & Change R2 & $\underline{P}$ \\
\hline .24 & .06 & .06 & $\overline{N S}$ \\
\hline .32 & .11 & .05 & NS \\
\hline .56 & .31 & .20 & 001 \\
\hline 27 & .07 & .07 & .05 \\
\hline .29 & .08 & .01 & NS \\
\hline .32 & .10 & .02 & NS \\
\hline .16 & .03 & .03 & $\mathrm{~N}$ \\
\hline 18 & .03 & .00 & V \\
\hline .35 & .12 & .09 & \\
\hline
\end{tabular}

measuring any progress that has been made. Organizations can both start and facilitate this change process.

Leiter and Maslach offer the following examples of change in each of the six areas of work experience.

Workload - improving time management, creating blocks of uninterrupted time, developing more skills of more effective work habits

Control - increasing one's autonomy, increase room for showing leadership and other initiatives

Reward - asking for better job assignments, rewarding oneself, recognizing others, doing more of what you enjoy doing at work.

Community - working to improve communication with co-workers, helping and supporting co-workers

Fairness - promoting respect and civility in the hospital unit and beyond

Values - promoting constructive values, keeping your integrity, being open and honest. 


\section{More effective restructuring and downsizing processes}

The fact that most downsizing and restructuring efforts in the 1990s fell short of achieving their objectives provided considerable material to help organizations better understand what worked and what did not work in their efforts .For example, Ludy (2009) suggests that organizations find other ways to reduce costs that never involve staff reductions. Burke (2003, pp5-6)) had earlier suggested the following actions to senior hospital and nursing leadership

1. They must develop a clear purpose of what they would like to accomplish and why (their motives). They must put all their cards on the table in an open, honest and complete way.

2. They must make a commitment to longterm efforts to turn around their situations; there is no quick fix.

3. Hospital and nursing leadership must be visible and available.

4. The senior management must spend time working together to clarify their objectives and motivations. Then senior management must spend time with lower levels of hospital administration communicating these objectives, strategies and motivations and soliciting input.

5. They must make resources available during this transition period (time, financial).

6. These efforts should be undertaken in cooperation with the nursing associations.

7. The process must be a collaborative effort in which ownership, responsibility and accountability is widely shared. .

8. Data must be collected from throughout hospitals to examine events of the past few years (what worked, what did not work). What is working well now, and what difficulties still exist that interfere with unit effectiveness and patient care.
9. Problem diagnoses and problem solving teams need to be developed, trained and used.

10. Small irritations need to be addressed immediately; small wins acknowledged and celebrated.

11. Accountability for solutions and progress must be clearly identified and delegated. Follow up activities need to be undertaken to ensure that actions are being developed and implemented, and data collected to monitor their progress and effectiveness.

12. The how that underlies revitalization efforts is likely to be more important than the specific what is being done in the success of these efforts.

13. There is an important need to release any negative reactions, in a sense to grieve the events of the past few yeas, the loss of some friends who either voluntarily or involuntarily felt their units, and the unfairness of the transition process. Nursing staff must deal with the pain of the past before they can come to grips with the demands of the present and future.

14. Trust of senior hospital management needs to be re-established and strengthened.

15, Senior hospital leadership must acknowledge any unintended consequences of the transition.

16. Nursing staff must understand the vision for the future (goals, mission, new behaviors, new program undertakings).

17. Nursing staff need to know where they and the hospital are headed.

18. Communication -lots, using various media with some repetition. Personal contact - one-to-one, and in work teams - is a must.

19. Senior hospital and nursing leadership needs to be involved, show enthusiasm and excitement, be patient since change 
will not happen over night, and anticipate mistakes and difficulties.

20. Realize the importance of teams during the revitalization process. Teams invite participation, offer support to members, and may produce greater and more creative results.

21. It is important to view recovery and revitalization as an opportunity.

22. Patient care must be the paramount objective.

\section{Conclusions}

"Insanity is doing the same thing but expecting different outcomes."

Private sector organizations embarked on widespread restructuring and downsizing efforts in the 1990s to become more competitive. Evaluations of these efforts indicated that most failed to achieve their business and financial objectives while creating far-reaching dissatisfaction and anger among employees, both survivors and victims (Ludy, 2009). Healthcare organizations, primarily hospitals, also undertook massive restructuring and downsizing efforts at the same time, following the approaches taken by the private sector, in response to government funding cutbacks. There efforts were also found to not reduce costs, but create demoralization in staff and place patient care at risk. Baumann and Blythe (2003) in fact believe that the application of the business cost cutting model to health care settings was inappropriate since patient care relies on knowledge, skills and social relations.

But these efforts, though most had failed, led to considerable learning of how to better go about organizational restructuring and downsizing (Cascio, 2002, 1998, 1995, 1993). Organizations today facing these difficult and complex transitions should be better prepared to undertake them.

Now, almost two decades later, the health care sector in many provinces, sates and countries are again contemplating restructuring and downsizing initiatives in response to another round of budget deficits - déjà vu. In some cases (e.g., California, Ontario) it seems as if they are going about it I the same way that the health care sector and hospitals approached this crisis in the 1990s by using widespread layoffs. We know that this will not work out well. Hopefully some hospitals and health care regions will use available research findings documenting both the earlier failures and what seemed to work offering a "better way forward" as they proceed.

\section{Research limitations}

This research has some limitations which should be noted to permit readers to put the results in context. First, while relatively large, the sample was a convenience sample and perhaps not representative of all nursing staff in California. Second, all data were collected using self-report surveys raising the slight possibility of response set tendencies and common method biases. Third, many of the work and health outcomes were themselves moderately inter-correlated. Fourth, issues of causality cannot be addressed since data were collected at only one point in time.

\section{Future research directions}

Many important research opportunities are likely as the health care sector in many countries face restructuring and cost-cutting. First, more studies using larger and more representative samples need to be done to document the impact of these efforts on nursing staff, patient care , hospital functioning, and actual costs themselves. Second, longitudinal research is needed to determine cause-effect relationships between restructuring and downsizing efforts, and how these are being implemented, and central outcome measures. Third, evaluation research of various approaches to increasing levels of the work experiences proposed by Leiter and Maslach (2005) need to be undertaken. These studies could also incorporate measures of hospital restructuring, downsizing and cost-cutting processes and efforts to improve these processes. 


\section{References}

Aiken, L. H., \& Fagin, C. M. (1997) Evaluating the consequences of hospital restructuring. Medical Care, 35, 1-4.doi:10.1097/00005650-19971000100001

Aiken, L. H., Sochalski, J., \& Anderson, G.F. (1996) Downsizing the hospital nursing workforce. Health Affairs, 15, 88-92. doi:10.1377/hlthaff.15.4.88, PMid:8991258

Aiken, L.H., Smith, H. L., \& Lake, E. T (1994) Lower medicare mortality among a set of hospitals known for good nursing care. Medical Care, 32, 771-787. doi:10.1097/00005650-199408000-00002 PMid:8057694

Aiken, L. H., Clarke, S. P., Sloane, D. M., \& Sochalski, J. A. (2001) An international perspective on hospital nurses' work environments: The case for reform. Policy, Politics and Nursing, 2, 255-263. doi:10.1177/152715440100200402

Armstrong-Stassen, M., Cameron, S. J., \& Horsburgh, M. E. (1996) The impact of organizational downsizing on the job satisfaction of nurses. Canadian Journal of Nursing Administration, 9, 8-32. PMid:9016004

Bakker, A. B., \& Leiter, M. P, (2010) Work engagement: A handbook of essential theory and research. New York: Psychology Press.

Baumann, A., \& Blythe, J. (2003) Restructuring, reconsidering, reconstructing: Implications for health human resources. International Journal of Public administration. 26, 1561-1580. doi:10.1081/PAD-120024411

Baumgart, A. J., (1997) Health reform and nursing labor market trends in Canada. Medical Care, 35, 124-131. doi:10.1097/00005650-199710001-00016 PMid:9339783
Blythe, J., Baumann, A., \& Giovannetti, P. (2001) Nurses' experiences of restructuring in three Ontario hospitals. Journal of Nursing Scholarship, 33, 61-68. doi:10.1111/j.1547-5069.2001.00061.x PMid:11253584

Brannon, R. L. (1996) Restructuring hospital nursing: Reversing the trend toward a professional work force. International Journal of Health Services, 26, 643. doi:10.2190/ AERK-G2VH-KMUQW5VD, PMid:8906443

Brown, C., Arnetz, B., \& Petersson, O. (2003) Downsizing within a hospital: Cutting care or just costs. Social Science and Medicine, 57, 1539-1546. doi:10.1016/S0277-9536(02)00556-7

Buchan, J., Hancock, C., \& Rafferty, A.M.(1997) Health sector reform and trends in the United Kingdom hospital workforce. Medical Care, 35,143-149. doi:10.1097/00005650-199710001-00018, PMid:9339785

Burke, R. J. 2004) Implementation of hospital restructuring and nursing staff perceptions of hospital functioning. Journal of Health Organization and Management, 18, 279-289. doi:10.1108/14777260410554287

Burke, R. J. (2003) Nursing staff attitudes following restructuring: The role of perceived organizational support, restructuring processes and stressors. International Journal of Family, 4, 49-62.

Burke, R. J., \& Nelson, D. L. (1998) Downsizing, restructuring and privatization: A North American perspective. In M. K. Gowing, J. D. Kraft \& J. C. Quick (eds.) The new organizational reality: Downsizing, restructuring and revitalization. Washington, D. C.: American Psychological Association, pp. 21-54. doi:10.1037/10252-001 
Cameron, K. (1994) Strategies for successful organizational downsizing. Human Resources Management, 33, 189-221. doi:10.1002/hrm.3930330204

Cameron, K., Freeman, S. J., Mishra,A. K. (1991) Best practices in white-collar downsizing: Managing contradictions. Academy of Management Executive, 5, 57-73

Cascio, W. F. (2002) Responsible restructuring: Creative and profitable alternatives to layoffs. San Francisco: Berrett0-Koehler.

Cascio, W. F, (1998) Learning from outcomes: Financial experiences from 311 firms that have downsized. In M. K. Gowing, J. D. Kraft \& J. C Quick (eds.) The new organizational reality: Downsizing, restructuring and revitalization. Washington, D. C.: American Psychological Association. pp. 55-70. doi:10.1037/10252-013

Cascio, W. F. (1995) Whither industrial and organizational psychology in a changing world of work? American Psychologist, 50, 928-939. doi:10.1037/0003-066X.50.11.928

Cascio, W. F. (1993) Downsizing: What do we know $>$ ? What have we learned? Academy of Management Executive, 7, 95-104.

Derogatis, L.R., Lipman, R.S., Rickels, R. S., Uhlenhuth, E, H., \& Covi, L. (1974) The Hopkins symptom Checklist (HSCL): A self-report symptom inventory. Behavioral Science, 19, 1-15. doi: 10.1002 /bs.3830190102 PMid:4808738

Gowing, M. K., Kraft, J. D., \& Quick, J. C. (1998) The new organizational reality: downsizing, restructuring and revitalization. Washington, D. C: American Psychological Association. doi:10.1037/10252-000
Kets de Vries, M. F R. \& Balazs, K. (1997) The downside of downsizing. Human Relations, 30, 11-30. doi:10.1177/001872679705000102

Kovner, C., \& Gergen, P. J., (1998) Nurse staffing levels and adverse advents following surgery in US hospitals. Image: Journal of Nursing Scholarship, 30, 3156-321. doi:10.1111/j.1547-5069.1998.tb01326.x

Laschinger, .H K. S., Sabiston, J.A., Finegan, J., Shamian, J. (2001) Voices from the trenches: Nurses' experiences of hospital restructuring in Ontario. Canadian Journal of Nursing Leadership 14, 6-13.

Leiter, M. P., \& Maslach, C. (2005) Banishing burnout: Six strategies for improving your relationship with work. San Francisco: Jossey-Bass.

Ludy, P. J. (2009) Profit building: Cutting costs without cutting people. San Francisco: Berrett-Koehler.

Maslach, C., Jackson, S. E., \& Leiter, M. P. (1996) The Maslach Burnout Inventory. 3rd ed. Consulting Psychologists Press. Palo alto, CA.

McKee, M., Aiken, L., Rafferty, A. M., \& Sochalski, J. (1998) Organizational change and quality of health care: An evolving international agenda. Quality in Health Care, 7, 37-41. doi:10.1136/qshc.7.1.37

Mesch, D. J., McGrew, J. H., Pescosolido, B. A., \& Haugh, D. F. (1999) The effects of hospital closure on mental health workers: An overview of employment, mental and physical health, and attitudinal outcomes. Journal of Behavioral Health Services and Research, 26, 305317. doi:10.1007/BF02287275 PMid:11571778

Muller-Mundt, G. (1997) trends in hospital restructuring and the impact on the workforce in Germany. Medical Care, 35, 132-142. doi:10.1097/00005650199710001-00017 
Noer, D. (1993) Healing the wounds: Overcoming the trauma of layoffs and revitalizing downsized organizations. San Francisco: Jossey-Bass.

O'Neill, H. M., \& Lenn, J. (1995) Voices of survivors: Words that downsizing CEOs should hear. Academy of Management Executive, 9, 23-34

Quinn, R. P., \& Shepard, L. J. (1974) The 1972-73 Quality of Employment Survey. Institute for Social Research, University of Michigan, ann Arbor, MI>

Reinhardt, U. E., (1996) Spending more through "cost control": Our obsessive quest to gut the hospital. Health Affairs, 45, 145-154. doi:10.1377/hlthaff.15.2.145 PMid:8690372

Robertson, R., \& Dowd, S. B. (1996) The effects of hospital downsizing on staffing and quality of care. Health Care Supervisor. 12, 50-56.

Schaufeli, W. B., \& Bakker, A. B. (2003) Utrecht Work Engagement Scale: Preliminary Manual. Department of Psychology, Utrecht University, The Netherlands.

Shanahan, M., Brownell, M. D. \& Roos, N. P. (2001) The unintended and unexpected impact of downsizing: Costly hospitals become more costly. Medical Care, 37, 123-134.

Shortell, S. M., \& O’Brien, J. L., \& Carman, J. M.(1995) Assessing the impact of continuous quality improvement/total quality management: Concept versus implementation. Health /Services Research, 30, 377-401. PMid:7782222 PMCid:1070069

Sochalski, J., Aiken, L. H., \& Fagin, C. M. (1997) Hospital restructuring in the United States, Canada, and Western Europe: An outcomes research agenda. Medical Care, 3, 13-25.
Woodward, C. A., Shannon, H.; S., Cunningham, C., McIntosh, J., Lendrum, B., Rosenblum, D. \& Brown, J.(1999) The impact of re-engineering and other cost reduction strategies on the staff of a large teaching hospital. Medical Care, 37, 556-569 doi:10.1097/00005650199906000-00005, PMid:10386568

Wright, B., \& Barling, J. (1998) The executioner's song: Listening to downsizers reflect on their experiences, Canadian Journal of Administrative Sciences, 15, 339-355. doi:10.1111/j.1936-4490.1998 .tb00176.x 